\title{
Designation of the Type Strain of Vibrio parahaemolyticus and Description of 200 Strains of the Species
}

\author{
T. FUJINO, R. SAKAZAKI, and K. TAMURA
}

\begin{abstract}
Department of Bacteriology and Serology, The Research Institute for Microbial Diseases, Osaka University, Osaka, and Department of Bacteriology 1, National Institute of Health, Tokyo, Japan
\end{abstract}

\begin{abstract}
Strain EB 101 (ATCC 17802) is designated the type strain of Vibrio parahaemolyticus (Fujino et al.) Sakazaki, Iwanami, and Fukumi, and the morphological, physiological, biochemical, and serological characteristics of this strain are described. The characteristics of the type strain are compared with those of 200 other strains of this species.
\end{abstract}

During an outbreak of "shirasu" food poisoning, Fujino et al. (2) isolated and described a strain (subsequently referred to by Fujino as strain EB 101) of a new species which they named Pasteurella parahemolytica (sic). Later, Sakazaki, Iwanami, and Fukumi (11) proposed a new combination, Vibrio parahaemolyticus, for this species. Fujino deposited strain EB 101, on which Fujino et al. (2) based their original description, in the American Type Culture Collection (ATCC), Rockville, Md. on 5 May 1965. However, Fujino et al. (2) did not designate EB 101 as the type strain for this species. Although Sakazaki (10) suggested that strain EB 101 (ATCC 17802) be recognized as the type strain for $V$. parahaemolyticus without making a definite statement, he was under the impression that the strain had been established as the type strain for $P$. parahaemolytica by Fujino's deposition of the strain in the ATCC. However, since the mere deposition of a strain in the ATCC (or any other collection) does not by itself effect the establishment of a type strain, the type strain for $V$. parahaemolyticus has not been properly designated. The purpose of this report is to designate the type strain of $V$. parahaemolyticus and to provide a more comprehensive description of this species on the basis of a study of 200 strains.

\section{MATERIALS AND METHODS}

Strains. $P$. parahaemolytica strain EB 101 was isolated by Fujino et al. (2) from "shirasu" (boiled and semi-dried sardines) implicated in an outbreak of food poisoning. A descendant of this strain was deposited in the ATCC as $V$. parahaemolyticus 17802.

The 200 strains of $V$. parahaemolyticus included were selected at random from a large collection accumulated over a ten-year period. One hundred of these strains were isolated from stool specimens from human patients with gastroenteritis, and the remaining 100 were from marine sources.

Methods. The procedures used to study these strains were described by Sakazaki et al. $(9,11)$. Møller broth was used for amino-acid decarboxylase tests. Sugar reactions were tested in the MOF medium described by Leifson (6). Growth in different concentrations of $\mathrm{NaCl}$ was determined in $1 \%$ Trypticase (BBL) peptone solution at $\mathrm{pH} 7.0$. Growth at $42 \mathrm{C}$ was determined in $1 \%$ Trypticase water containing $2 \% \mathrm{NaCl}$. The Kanagawa reaction, involving a thermostable hemolysin produced by $V$. parahaemolyticus, was performed with Wagatsuma agar plates containing $2 \%$ washed, fresh, human erythrocytes. The base composition of the deoxyribonucleic acid was determined by thermal melting points as described by Hill (4).

\section{RESULTS}

The characteristics of EB 101 and the 200 other strains of $V$. parahaemolyticus are summarized in Table 1. The results of the human and marine strains are recorded separately to facilitate a comparison of each characteristic with strain EB 101.

All the strains contained gram-negative, straight, or occasionally slightly curved, rodshaped cells which exhibited pleomorphism. They were motile by means of a single polar flagellum when cultured in liquid medium.

All strains grew well in peptone water containing 3 and $6 \% \mathrm{NaCl}$, but poor or no growth occurred in salt-free peptone water and peptone water containing $10 \% \mathrm{NaCl}$. Most of the strains grew in peptone water with $8 \%$ salt, although strain EB 101 and two of the 100 strains of human origin grew very poorly. With the exception of strain EB 101 and a few others, most strains grew at $42 \mathrm{C}$ in peptone water containing $2 \%$ salt. 
TABLE 1. Characteristics of the type strain and 200 other strains of $V$. parahaemolyticus from human and marine sources

\begin{tabular}{|c|c|c|c|}
\hline \multirow[b]{2}{*}{ Characteristics } & \multirow[b]{2}{*}{$\begin{array}{c}\text { Type } \\
\text { strain } \\
\text { EB } \\
101\end{array}$} & \multicolumn{2}{|c|}{$\begin{array}{l}\text { No. of strains } \\
\text { giving positive } \\
\text { reaction }\end{array}$} \\
\hline & & $\begin{array}{c}\text { Human } \\
\text { sources } \\
(100 \\
\text { strains })\end{array}$ & $\begin{array}{c}\text { Marine } \\
\text { sources } \\
(100 \\
\text { strains })\end{array}$ \\
\hline Gram-negative, asporogenous & $t^{a}$ & 100 & 100 \\
\hline Motility & + & 100 & 100 \\
\hline Polar monotrichous & + & 100 & 100 \\
\hline $\begin{array}{l}\text { Growth in } 1 \% \text { Trypticase } \\
\text { broth with: }\end{array}$ & & & \\
\hline $0 \% \mathrm{NaCl}$ & - & 0 & 0 \\
\hline $8 \% \mathrm{NaCl}$ & - & 98 & 100 \\
\hline $10 \% \mathrm{NaCl}$ & - & 0 & 0 \\
\hline Growth at $42 \mathrm{C}$ & - & 96 & 94 \\
\hline Growth on TCBS agar & + & 96 & 98 \\
\hline Indophenol oxidase & + & 100 & 100 \\
\hline Catalase & + & 100 & 100 \\
\hline Nitrate to nitrite & + & 100 & 100 \\
\hline Nitrate to $\mathrm{N}_{2}$ gas & - & 0 & 0 \\
\hline Indole & + & 98 & 100 \\
\hline Acetylmethylcarbinol & - & 0 & 0 \\
\hline Hydrogen sulfide (Kligler) & - & 0 & 0 \\
\hline Phenylalanine deaminase & - & 0 & 0 \\
\hline Lysine decarboxylase & + & 97 & 96 \\
\hline Arginine dihydrolase & - & 0 & 0 \\
\hline Ornithine decarboxylase & + & 95 & 96 \\
\hline Urease (Christensen) & - & 0 & 0 \\
\hline Gelatinase & + & 100 & 100 \\
\hline Chitinase & $(+)$ & 99 & 100 \\
\hline Citrate (Simmons) & + & 100 & 100 \\
\hline Malonate & - & 0 & 0 \\
\hline Alginate & - & 0 & 0 \\
\hline Starch hydrolysis & + & 100 & 100 \\
\hline Casein hydrolysis & + & 100 & 100 \\
\hline Glucose, gas & - & 0 & 0 \\
\hline \multicolumn{4}{|l|}{$\begin{array}{l}\text { Acid under petrolatum seal } \\
\text { from: }\end{array}$} \\
\hline Glucose & + & 100 & 100 \\
\hline Arabinose & + & 78 & 83 \\
\hline Cellobiose & $(+)$ & 63 & 44 \\
\hline Galactose & + & 100 & 100 \\
\hline Lactose & - & 0 & 0 \\
\hline Fructose & + & 100 & 100 \\
\hline Maltose & + & 100 & 100 \\
\hline Mannose & + & 100 & 100 \\
\hline Melezitose & - & 0 & 0 \\
\hline Melibiose & - & 13 & 18 \\
\hline Raffinose & - & 0 & 0 \\
\hline Rhamnose & - & 0 & 0 \\
\hline Ribose & + & 100 & 100 \\
\hline Sorbose & - & 0 & 0 \\
\hline Sucrose & - & 0 & 2 \\
\hline Trehalose & + & 100 & 100 \\
\hline Xylose & - & 0 & 0 \\
\hline Adonitol & - & 0 & 0 \\
\hline Dulcitol & - & 0 & 0 \\
\hline Ery thritol & - & 0 & 0 \\
\hline Inositol & - & 0 & 0 \\
\hline
\end{tabular}

\begin{tabular}{l|r|r|r}
\hline Mannitol & + & 100 & 100 \\
Sorbitol & - & 3 & 8 \\
Salicin & - & 0 & 0 \\
Alpha-methyl-D-glucoside & - & 0 & 0 \\
Beta-methyl-D-glucoside & + & 100 & 100 \\
Esculin hydrolysis & + & 99 & 100 \\
Kanagawa reaction & - & 98 & 0 \\
H antigens specific for $V$. & & & \\
$\quad$ parahaemolyticus & + & 100 & 100 \\
\hline
\end{tabular}

${ }^{a}+$, Positive reaction within $48 \mathrm{~h}$ of incubation; $(+)$, positive reaction after $48 \mathrm{~h}$ or more of incubation; ,- no reaction.

All strains produced catalase and indophenol oxidase, reduced nitrate to nitrite, liquefied gelatin, and hydrolyzed casein. They did not produce phenylalanine deaminase, urease, or hydrogen sulfide, reduce nitrate to nitrogen gas, produce acetylmethylcarbinol, or utilize malonate or alginate. Most of the strains produced indole and lysine and ornithine decarboxylases, utilized citrate on Simmons agar, and hydrolyzed chitin and starch, but occasional strains, including EB 101, gave negative results in some of these tests.

Acid without gas was produced by all of the strains from glucose, fructose, galactose, maltose, mannose, ribose, trehalose, and mannitol under aerobic as well as anaerobic conditions (fermentation). Lactose, melezitose, raffinose, rhamnose, sorbose, xylose, adonitol, dulcitol, erythritol, inositol, salicin, and alpha-methyl glucoside were not fermented by any strain. Sucrose and sorbitol were not attacked by most strains. Cellobiose was not fermented within 24 $h$, but many strains produced acid from this sugar after several days of incubation. The fermentation of arabinose and the hydrolysis of esculin varied among strains.

Most of the human strains gave a positive Kanagawa reaction, whereas all strains from marine sources and strain EB 101 failed to hemolyze human erythrocytes.

Strain EB 101 was serologically identified with serotype $01: \mathrm{K} 1$ of $V$. parahaemolyticus. The $\mathrm{H}$ antigen of strain EB 101 was identical to that which characterizes the species.

The guanine plus cytosine content of the deoxyribonucleic acid preparation from strain EB 101 was $44.5 \mathrm{~mol} \%$.

\section{DISCUSSION}

Sakazaki et al. (11) pointed out that some characteristics, such as growth on MacConkey agar or in peptone water containing $8 \% \mathrm{NaCl}$, tend to be lost in old cultures of $V$. parahaemolyticus, and they observed that utilization of 
citrate on Simmons' agar and liquefaction of gelatin by strain EB 101 are inconsistently recorded by various workers $(2,3,5,7,13,15)$. Sakazaki et al. (11) and Fujino et al. (3) thought that these reported differences of characteristics would be due to the technique employed, and they concluded that the strain described as $P$. parahaemolytica should be included in the species $V$. parahaemolyticus. Sakazaki, Iwanami, and Tamura (12) and Terada (14) also reported that strains of $V$. parahaemolyticus could be distinguished from other marine organisms because of the specific flagellar antigen. The guanine plus cytosine content of the deoxyribonucleic acid of strain EB 101 closely conforms to that of $V$. parahaemolyticus strains reported by Citarella and Colwell (1).

As mentioned above, the original description of $P$. parahaemolytica by Fujino et al. (2) was based on a study of a strain which was not given a designation by Fujino et al. but which was subsequently designated EB 101 by Fujino. This strain, EB 101, is here designated the type of $V$. parahaemolyticus.

\section{REPRINT REQUESTS}

Address reprint requests to: Dr. Riichi Sakazaki, Department of Bacteriology 1, National Institute of Health, 10-35 Kamiosaki 2-chome, Shinagawa-ku, Tokyo, Japan.

\section{LITERATURE CITED}

1. Citarella, R. V., and R. R. Colwell. 1970. Polyphasic taxonomy of the genus Vibrio: polynucleotide sequence relationship among selected Vibrio species. J. Bacteriol. 104:434-442.

2. Fujino, T. 1951. Bacterial food poisoning. (In Japanese) Saishin Igaku 6:263-271.

3. Fujino, T., T. Miwatani, J. Yasuda, M. Kondo, Y. Takeda, Y. Akita, K. Kotera, M. Okada, H. Nishimura, Y. Shimizu, T. Tamurá, and Y. Tamura. 1965. Taxonomic studies on the bacterial strains isolated from cases of 'shirasu' food- poisoning (Pasteurella parahaemolytica) and related microorganisms. Biken J. 8:63-71.

4. Hill, L. R. 1968. The determination of deoxyribonucleic acid base composition to bacterial taxonomy, p. 186-199. In B. M. Gibbs and D. A. Shapton (ed.), Identification methods for microbiologists, part B. Academic Press Inc., London.

5. Kosuge, T. 1959. Studies on the halophilic food poisoning bacilli named by Takikawa et al. I. (In Japanese) J. Jap. Ass. Infect. Dis. 33:841-843.

6. Leifson, E. 1963. Determination of carbohydrate metabolism of marine bacteria. J. Bacteriol. 85: 1183-1184.

7. Miyamoto, Y., K. Nakamura, and K. Takizawa. 1961. Pathogenic halophiles. Proposals of a new genus 'Oceanomonas' and of the amended species names. Jap. J. Microbiol. 5:477-486.

8. Miyamoto, Y., K. Nakamura, K. Takizawa, and T. Kodama. 1961. Carangina fish poisoning. III. (In Japanese) Jap. J. Pub. Health 8:703-707.

9. Sakazaki, R. 1965. Vibrio parahaemolyticus. Isolation and identification. Nihon Eiyo, Tokyo.

10. Sakazaki, R. 1968. Proposal of Vibrio alginolyti. cus for the biotype 2 of Vibrio parahaemolyticus. Jap. J. Med. Sci. Biol. 21:359-362.

11. Sakazaki, R., S. Iwanami, and H. Fukumi. 1963. Studies on the enteropathogenic, facultatively halophilic bacteria, Vibrio parahaemolyticus. I. Morphological, cultural and biochemical properties and its taxonomical position. Jap. J. Med. Sci. Biol. 16:161-188.

12. Sakazaki, R., S. Iwanami, and K. Tamura. 1968. Studies on the enteropathogenic, facultatively halophilic bacteria, Vibrio parahaemolyticus. II. Serological characteristics. Jap. J. Med. Sci. Biol. 21:313-324.

13. Sekine, Y., S. Horie, and K. Saheki. The so-called pathogenic halophilic bacteria and the other group of allied organisms. Bull. Jap. Soc. Fish. 28:920-923.

14. Terada, T. 1968. Serological properties of Vibrio parahaemolyticus antigen. II. Flagellar antigen. (In Japanese) Nippon Saikingaku Zasshi 23:767-771.

15. Yamaji, Y., T. Kojima, T. Shiba, T. Ishizeki, and S. Hatta. 1957. Studies on the pathogenic halophiles. I. Biological characters and salt tolerance. (In Japanese) Nippon Saikingaku Zasshi 13:63-69. 